\title{
The Unbearable Likeness of Being a Tourist: Expats, Travel and Imaginaries in the Neo-colonial Orient
}

\author{
Roger Edward NORUM• \\ Institute of Social and Cultural Anthropology \\ University of Oxford
}

\begin{abstract}
This paper considers the impact of shared imaginaries of mobility among socalled elite, mobile professionals - early-career expatriates living in Nepal for a period of one to three years. Based on 18 months of fieldwork among expatriates in Kathmandu, I explore the ways in which these actors construct, navigate and narrativise the boundaries between themselves and the many tourists who visit Nepal each year. While in some transnational contexts, these guests may seek to align themselves with other guests such as tourists and foreign residents as a means of asserting and expressing shared commonalities of transnationality and mobility, expatriates in Kathmandu are keen to highlight perceived distance between themselves and other guests as much as they are the perceived proximities between themselves and native Nepalis. In focusing on this former interaction, I show that tourist imaginaries become important means for expatriates to negotiate difference as they learn their new local identities in a context of spatial and temporal transience. Though the academic literatures of migration and tourism have developed more or less in isolation from one another, these two spheres of mobility are in fact very much interrelated. I suggest that anthropological research into the self-conceptions of mobile professionals take into consideration other non-local groups with whom they share local spaces, since these actors can be used instrumentally as a means of strengthening both group and individual identities. If anthropology engages effectively with the interactions between hosts and guests in colonial spaces, I argue that just as much can be gleaned by looking at engagements between guests and other guests. Through a consideration of these border zones of encounter, anthropologists can illustrate ethnographically how individual expatriate identities are negotiated within communities of elite, mobile professionals.
\end{abstract}

Keywords: elites, expatriates, imaginaries, mobilities, Nepal, tourism.

\section{Introduction}

... I was sitting working at Or2K

[a vegetarian café in Kathmandu] and these tourists sit down next to me and just start talking to me. They're asking the best way to walk to New Road, so I told them: just walk straight down Kantipath—right? —instead of

-email:roger.norum@anthro.ox.ac.uk. Roger Norum is a DPhil candidate at the University of Oxford and a Research Student at the Centre on Migration, Policy and Society (COMPAS), Oxford. My thanks go to Bridget Anderson, Sondra Hausner, Marthe Achtnich, Patrick Alexander, Mary Mostafanezhad, Sam Mejias and Alejandro Reig for insightful comments on earlier versions of this paper, and to editors Liviu Chelcea, Mari Korpela and Raluca Nagy for their invaluable critique, encouragement and humour. Above all, my gratitude goes to the many participants who made this research possible. 
that convoluted route through Thamel. And then at one point, this one guy, he starts telling me all these things about Kathmandu. Like, oh, where to get the best coffee in Thamel and what bars are good and which trekking company will rip you off. And it was like, 'Uh, no dude, I am not a tourist. I live here'. (Thomas, American, 32 years old, emphasis his)

The desire for tourists to distinguish themselves as somehow different from other tourists seems to be a core experience of the tourist encounter. In writing about this mode of highlighting difference between cultured and uncultured, or between engaged and ignorant, Boorstin (1963: 85; cited Culler, 1981) comments, 'The traveler, then, was working at something; the tourist was a pleasure seeker. The traveler was active; he went strenuously in search of people, of adventure, of experience. The tourist is passive; he expects interesting things to happen to him.' The fluid lines between archetypal figures of mobility such as the tourist, traveller, explorer, adventurer and expatriate are regularly redrawn by actors looking to self-identify against others, or with Others (see MacCannell, 1999[1976]: 103-104). The moral privileging of travellers over tourists - and the binary oppositions between the two - has become a core aspect of modern-day travel. MacCannell (1999[1976]: 10) explains that this strategy of distancing and distinguishing oneself from actors with whom one might share one or more common traits (i.e. homeland, language, class, etc.) is often based on the desire to engage with the Other on a more substantive level:
The touristic critique of tourism is based on a desire to go beyond the other 'mere' tourists to a more profound appreciation of society and culture ... All tourists desire this deeper involvement with society and culture to some degree; it is a basic component of their motivation to travel.

The tourist's belief is that tourists can only ever achieve a superficial understanding of the society and people they are travelling among. The traveller, however, hyper-conscious of the pitfalls of buying into massmediated tourist consumption, is capable of more substantive engagement with his hosts and of reaching enlightenment through a greater appreciation of the authentic. Such discourses of authenticity linked to Western society's undying push towards progress and modernization have strongly informed the modern experience of travel from global North to global South. If, as James Clifford (1992: 112) has argued, the nostalgic 'theme of the vanishing primitive, of the end of traditional society ... is pervasive in ethnographic writing, it has played an equally central and seminal role in the development of the global travel industry.

The experiences of expatriates - elite, educated, privileged and very mobile professionals who reside somewhere on the host-guest continuum between native and tourist - have gone largely overlooked by anthropologists, geographers and sociologists otherwise interested in transnationalism and the movement of peoples ${ }^{1}$. Fechter and Walsh (2010) have drawn attention to the overwhelming attention in migration research to focus on the movement of poorly- 
skilled, economically-impoverished peoples from developing countries to developed ones. As a result, the very term migration has become a loaded one which for many years exclusively considered this trajectory from global South to North. Furthermore, much anthropological research on so-called developing societies has tended to look at their hosts, rather than the guests. ${ }^{2}$ Yet logic would suggest that some of the most anthropologically compelling engagements between hosts and guests are observable across a range of social, cultural and geographic hierarchies in the spaces of the former colonies themselves (see Fechter and Walsh, 2010: 1201). If this is the case, then observing how these guests engage with other guests may offer just as much insight into group and individual identities among privileged communities. ${ }^{3}$

Though the academic literatures of migration and tourism have developed more or less in isolation from one another, these two spheres of mobility are in fact very much interrelated. If differentiations 'between permanent and temporary moves is no more than an artefact of statistical convenience,' we can also be certain that distinctions between the two are nevertheless becoming increasingly blurred as a result of accelerating social, economic and technological change' (Bell and Ward, 2000: 104). Early literature on globalisation tended to reify members of the global, privileged workforce as 'transnational elite' (Friedman, 1999), 'transnationalist capitalist class' (Sklair 2001) and groups of 'professional transients' (Castells, 2000). Whether or not such broad characterisations are useful in the analytical toolbox, empirical and ethnographic data to back them up has been sporadic at best (Fechter, 2007).

As a contribution to a growing body of ethnographically-grounded research that theorises engagements of mobilities, this paper considers the extent to which the idea and practice of travel is embedded both in the spatial identities of modern-day Nepal and in the social identities of expatriates who live there. In querying the delineations commonly drawn between migration and tourism, I engage with intersecting forms of mobility to show how mobile actors must engage with others, with Others and with the various imaginaries of both in order to negotiate their local identities. In recent years, social scientists have made use of the concept of imaginaries to theorise a range of social phenomena (Taylor, 2002; see also Alexander forthcoming). Salazar (2012) describes the tourist imaginary as:
Stories, images, and desires, running the gamut from essentialized, mythologized, and exoticized imaginaries of otherness to more realistic frames of reference ... Marketers eagerly rely on them to represent and sell dreams of the world's limitless destinations, activities, types of accommodation, and peoples to discover and experience... a paradisiacal environment, a vanished Eden, where the local landscape and population are to be consumed through observation, embodied sensation, and imagination.

The essentialised, mythologised and exoticised notions of place commonly thought of as the domain of the tourist are contested and rebuked by 
actors who consider themselves above such conceptualisations. Although the frustrated expatriate introduced at the beginning of this article had only been living in Nepal for a few months at the time of the encounter, he readily proclaimed to the tourists next to him that he was definitely not one of them. This encounter of being perceived as a tourist (by a tourist) was echoed throughout my field, where I observed it to be a fundamental pivot of identity among expatriates in Kathmandu. ${ }^{4}$ In the pages that follow, I examine the line that is imagined and negotiated between expatriates and tourists in their shared social spaces. This boundary, constantly in flux, is drawn and redrawn around different actors in the spaces of host-guest relations, and deeply linked to concepts of "the foreign' embedded within imaginations of the host country.

Nepal has long existed as a mythical destination for travellers, with many parts of the country now frequently marketed by adventure tour operators as accessible, consumable Orients. During the 1950s, media outlets in the West commonly referred to Kathmandu as the 'forbidden kingdom'; one Newsweek article in 1955 even heralded the city as a 'genuine ShangriLa' (Liechty 2010: 267). As a result, at a time when early hippie types were filling up their VW buses with cheap petrol preparing for the mad scramble overland on shoestring budgets towards Asia, the images first broadcast to the world of Nepal were of an untamed and unseen exotic landscape, ripe for touristic plunder. The result of these fascinated, fantastical early media depictions of the Nepali exotic was that foreigners would inevitably arrive to the country with many hard-and-fast preconceptions of what it would be like.

In looking at the (sometimes binary) distinctions and boundaries drawn around the figure of 'tourist' that become embedded deeply within the everyday life of the expatriate resident in Kathmandu, I examine how expatriates negotiate notions of authenticity and legitimacy, often exhibiting high levels of self-consciousness vis-à-vis how 'authentic' they are perceived to be by others. Expatriates learn to negotiate an identity of their own around the identities of tourists in order to legitimise their own place as foreigners in the host society they are settled in.

In the following section, I present the ethnographic methods on which this article is based. I then examine the history of foreign tourists travelling to Nepal in the twentieth century, outlining how such actors became fundamental to the process by which Nepal opened itself up to the greater world and highlighting the exotic imaginaries that became intricately linked to the Nepali landscape and people. I follow this discussion with by an ethnographic examination of how expatriates see themselves as distinct from tourists. I offer, furthermore, how the image of the foreigner as tourist (and, latterly, as humanitarian patron) has become embedded in the cultural mythologies of Nepal and physical spaces of Kathmandu. I then conclude by showing how such research is relevant to and important for anthropological considerations of engagements of mobilities. 


\section{Methods and Methodology}

During my year and a half of fieldowrk in Kathmandu, my introduction to most expatriates happened largely organically. But my introduction to most expatriates happened largely organically: befriending one person, having them introduce me to one of their friends or work colleagues, and then watching the size of my network snowball from there. The result was that the expatriates who ended up becoming my subjects worked across a wide range of industries and institutions, from NGOs, UN bodies and development organisations, to private consultancies, journalistic outfits and language schools. They represented a range of nationalities, hailing primarily from Australia, America, the UK and several countries in Western Europe. In many ways, though, such distinctions mattered little when it came to the various boundaries of Kathmandu's expatriate community, which did not strictly define along national, organisational or industrial lines. Outside the office, for example, a Polish UNHCR intern was as likely to go out drinking with a US Embassy official as she was with a British photographer.

Much of my data was collected in Kathmandu's restaurants, cafes, bars and people's homes - the spaces of expatriate sociality. I utilised a range of ethnographic methods that included participant observation, informal conversation, semi-structured interviews, material gathered from local newspapers and the internet, and and dinner parties which I hosted that served as focus groups. Interviews were consistently recorded, transcribed and coded. Shore and Nugent (2002: 11 ), in their anthropological volume on transnational elites, ask the question, 'How far should the fact that [elites] are likely to read what we write about them temper our analysis?' While I cannot admit to having consciously tempered anything I have written, I have changed the names of all my subjects to preserve anonymity.

Becoming known among various pockets of the expatriate community legitimised me among new contacts, and at a certain point the collective knowledge of my presence in Kathmandu meant that a number of potential subjects ended up seeking me out on their own, expressing their interest to be interviewed so they could tell me 'about their lives'. Many subjects often expressed a strong, substantive interest in the conclusions I was to eventually draw from my observations. Several enquired whether they could read my thesis once I finished writing it, and whether, once published, it might be somehow used to 'help' them in their 'plight' (as one 30-year-old German woman put it). While it is not uncommon for an anthropologist's subjects to take an engaged interest in his research, I argue that my expatriate subjects' deep inquisitiveness with respect to my research betrayed a specific and unique self-consciousness regarding the various issues of individual and group identity that exist among expatriate communities.

Yet, despite my subjects' strong intellectual engagement with my research, fieldwork was hardly ever straightforward, simple or free of concerns. Bell and Ward (2000) have alluded to the methodological 
challenges associated with research on temporary mobility, obstacles which they tie largely to the duration, frequency and seasonality of such movements. My complications were rather more tied to my positionality in the expatriate community. In looking at actors on a similar social, class and educational level as myself, my research seemed to amplify the traditional ethnographic study of a 'local' community into what I, paraphrasing Jackson (1987), refer to as 'anthropology at home, abroad'.

I remember at an outdoor costume party one evening being presented to a group of people by Martin, a Scandinavian communications consultant in his early 30s. When he introduced me to his friends, Martin added with a smirk, 'He's a spy'. Flippant, jestful introductions such as Martin's were not uncommon experiences for me. While they ultimately enabled potential subjects to let down their guard around me, they also highlight the fact that my positionality was contested in many situations. Kulick and Wilson (1995) have written about the place of the anthropologist as, alternatively, an object of desire or as a desiring subject in the field. As a single Western male, it was important for me to remain conscious of how I was perceived by various subjects; this subjectivity proved an important aspect of my research.

\section{The great game: Taking advantage of Nepal}

Just as the global travel industry was undergoing immense changes with the advent of commercial air travel in the years following the Second World War, the tiny Kingdom of Nepal was beginning to open itself up to outsiders - a synchronicity which we might not see as entirely coincidental. Several years after Edmund Hilary and Tenzing Norgay's landmark ascent of Everest in 1953, the first official tourists arrived to Nepal: a group of two dozen wealthy, elderly Thomas Cook travellers on a side excursion while their British luxury cruise liner was docked in Bombay (Satyal, 1999: 74-75). The visitors lodged at the soon-to-become-legendary Royal Hotel (today's Yak and Yeti Hotel), a small but lively establishment built by a Russian ballet-dancer-turnedentrepreneur on one floor of a Nepali royal palace, and one of a dozen odd hotels and guesthouses in operation during Kathmandu in the 1950s. The Royal swiftly became the focal point of Kathmandu's fledgling expatriate social scene, hosting 'a steady stream of thirsty mountaineers, diplomats, explorers, spies, missionaries, aid workers, big-game hunters, and yeti enthusiasts - along with the rich and famous tourists'(Liechty, 2010: 254).

And what were they all coming for? During the 1950s and 1960s, physical infrastructure in Kathmandu, to say nothing of the rest of Nepal, was effectively non-existent. The capital was little more than a collection of cow pastures bedecked with the odd palace or government building, its valley filled with jade-green terraced fields. There were no roads (or petrol) anywhere to speak of; the country's first automobiles had to be transported in parts by porters to the capital, where they were then reassembled (Bindloss, 
Holden et al. 2009). Yet this lack of infrastructure was not considered a negative aspect by the earliest tourists, it was rather seen as a welcome detour from the busy, noisy, crowded and destitute parts of Asia. Being distinct and removed from the modernising world became much of Nepal's draw.

Kathmandu's allure as an isolated, undiscovered and mysterious destination was reflected in the writings of novelists who spent time in the city in these early days. One author described the city's very name as 'one of the best sounding place names in the world. Katmandu is up in the gazetteer's galaxy with Samarkand and Yucatan and Kandahar and Zanzibar: it belongs with Xanadu and the fictional Shangri-la... [It brings to mind] barbaric splendour at an Oriental world's end' (Simpson 1967: 1). The Flemish-Chinese author Han Suyin, resident in Nepal for several years, admitted she wanted to visit Kathmandu simply because of its name. She had '... believed in Kathmandu as in Father Christmas when I was six: knowing that there was no such person, yet mightily praying and hoping there was' (Han 1992 [1958]: 42-43). Danish author Eskelund (1959: 134; all cited Liechty, 2010: 266) described Kathmandu as "exactly how I imagined the East when I was a boy, longing to get away from Denmark'. This latter quote, interestingly, rather closely mirrors the words of a nineteen-yearold Gustave Flaubert, who a century earlier confided to his diary, 'It's the East forever, I was born to live there,' never having once set foot outside of France (Flaubert and Germain, 1987: $85)$.

By the dawn of the 1960s, the landscape for travellers had begun to change dramatically across many parts of Asia. The colonial era of travel, with the imagined narratives 'of tiger shoots and bazaars filled with the political intrigue of maharajas and princes' born out of it, largely drew to a close (Peissel 1966: 30). Hundreds of thousands of middle-class European and American youth were beginning their shoestring trips across the continent, escaping to South Asia on the search for some spiritual meaning in rejection of the dominant cultural values of modernity. The cultural accoutrements of the East began to lure Westerners discontent with their own societies. While religious scholars and academics had long engaged substantively with Eastern religions, for example, the travelling public - whether they did so from an armchair or a camper van — began to take interest in Buddhism and Hinduism, which were becoming 'widely accepted as antidotes to the ills of Western modernity' (Ortner 2000: 186; see also Moran 2004). By the mid1960 s, researchers, artists, hippies, overland travellers and Peace Corps volunteers soon outnumbered Nepal's wealthy visitors. Nepal's growth as a popular tourist destination thus arose largely due to the counterculture of 1960s Europe and North America, and by the 1970s, cheap living and legal marijuana had made Nepal 'probably the single biggest magnet in the world for the countercultural lifestyle' (Ortner, 2000: 186).

Liechty (2005: 23) observes that the lifestyles and subjectivities already extant in the West were being projected onto and reproduced in the East: ' ... cutting edge Western youth counterculture was indeed 'transported 
bodily' to this exotic Asian outpost where it became a continuation of the same 'scene' being lived out in London, San Francisco, Amsterdam and New York'. There were financial benefits, too, to taking the road to Kathmandu. One could make the 11,000-mile bus journey from Amsterdam to Kathmandu for a few hundred dollars, and once there you could get by for under a dollar a day (Liechty 2005: 23). This meant that one could work a few months at a non-committal job (as a waitress or a mechanic, say) at home, then spend the rest of the year travelling to (and living well in) Nepal.

The links between this mass middleclass exodus and the rite de passage known as the Grand Tour are hardly spurious. During the Grand Tour, young members of the British gentry and aristocracy travelled to central and southern European countries as a realworld enhancement of their classical educations and as a means of enhancing their social capital (Buzard, 1993: 100). Though the geography, demographics and mechanics of the Grand Tour had changed, the means by which young Westerners were seeking enlightenment - the experience of travel - had not. The same colonial knowledge systems that spawned a host of Orientalisms inevitably made 'The East' a resource for the Western popular imagination and a form of 'imaginative escape' for Westerners looking for a good time (Bishop, 1989: 7). After air travel became even more affordable during the 1970s, killing off the overland route, Nepal's hippie era ended with the Nepali government's outlawing of the sale and purchase of marijuana in 1973 and the subsequent rounding up of many foreigners loitering in Nepal on long-expired visas. This move coincided with the establishment of the Nepali Ministry of Tourism and the growth of a managed tourism industry (Liechty 2005: 26). By 1976, the number of visa-bearing foreign visitors to Nepal had grown to 100,000 , and a decade later it had risen to 265,943 (Central Bureau of Statistics 1990; Whelpton 2005; Liechty 2010). This figure has remained more or less stable since then, though the numbers have at times decreased due to the Maoist insurgencies which have plagued the country over the past decade or so (Pradhanang, 2009).

I want to briefly mention here the assumptions I am making in assigning notions of colonialism to present-day Kathmandu. Although Nepal was made a de facto British protectorate in 1816 under the auspices of the East India Company, the country never experienced any official historical period of colonial or imperial rule. I argue, however, that the gazes of foreigners must involve the negotiation not of a colonial past, but rather of a neocolonial present and its concomitant imaginaries (Norum forthcoming). This colonialism I refer to speaks to the imbalanced political and economic relationship engendered between aid dependent nations, of which Nepal has become something of a poster child, and the donor countries that provide regular financial sustenance to them. Recent work has shown how the post-colonial Self becomes an omnipresent force empowered by colonial and post-colonial historical processes which seek to 'develop the Other' (Armbruster, 2010). Such empowering processes often ignore the negative or detrimental aspects of a 
colonial heritage which has, over time, disempowered these very same Others. The result is that white foreigners (and whiteness) become imbued with 'professional' attributes and abilities, which can serve to further subjugate and constrain locals in the name of financial and cultural empowerment and social and political emancipation (Leggett, 2005: 1204).

\section{Expatriates (not) as tourists: The search for authenticity}

Western cultural productions about Nepal - stories, media accounts, travelogues and novels - persist in Westerners' mythologies of Nepal and serve to engender imaginaries which manipulate senses of expectation, anticipation and the 'pleasures of curiosity' (Chard, 1999: 32-33). But if the trope of travel is necessarily bound up in the identities of Nepal's expatriates, these identities have also developed around a self-identification that is explicitly distinct from tourists. Just as distinguishing oneself as not a tourist is a common practice among tourists themselves, the same proved very common among my expatriate informants. The following photograph (Figure 1) was posted in an album on Facebook by Morgan, a twentysomething American on a fellowship working for a local NGO. The caption to the photograph read,

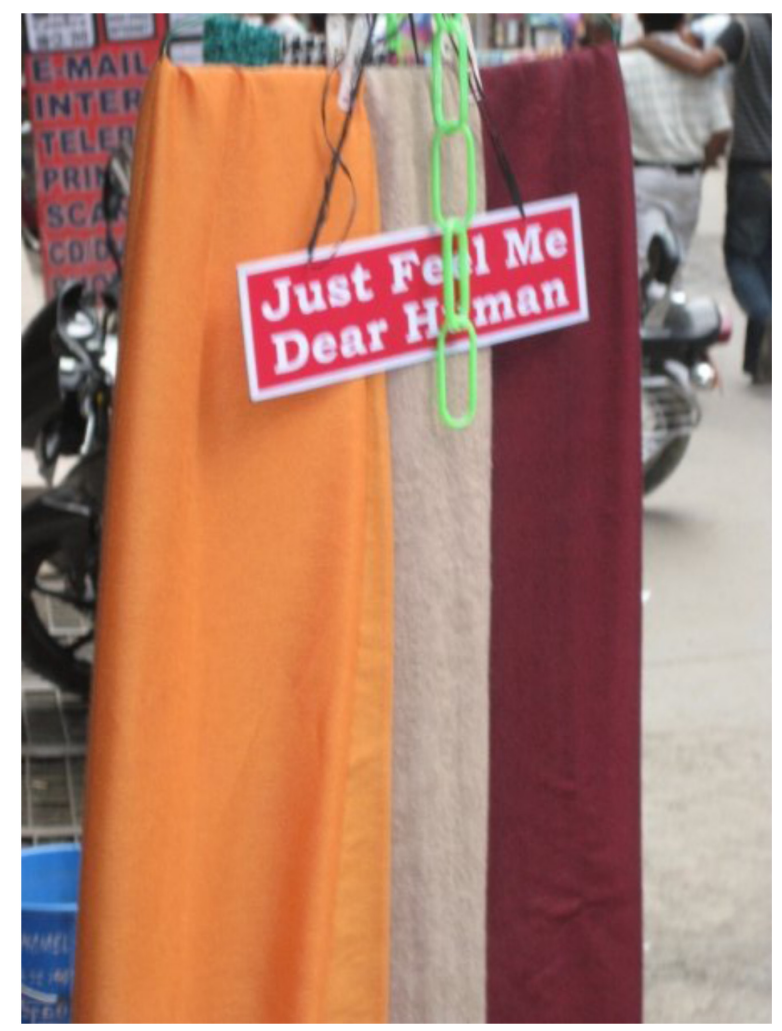

Figure 1: Morgan's Facebook album post 
In thamel, tourist section of town. hate thamel. hate tourists (am i allowed yet? pleeease?) LOVE this sign.

Posted a month or so after she had arrived to her two-year job posting in Kathmandu, Morgan's Facebook entry shows an acute awareness of expatriates' common process of selfidentification as distinct from tourists. But in what ways do expatriates see themselves as different from tourists?

Lizabeth is an Australian in her mid-20s who worked for a year at a health-related NGO in Nepal before moving to Bangladesh. An avid mountain biker with long, curly blonde hair, Lizabeth had initially come to Nepal when she was 19 on a trekking holiday with friends before returning as part of a fellowship program run by the Australian government. In an email, she explained to me some of the traits that distinguish expatriates from tourists:

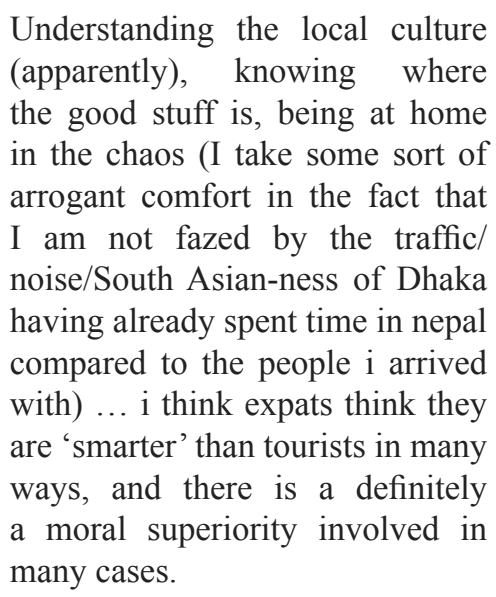

Understanding the local culture (apparently), knowing where the good stuff is, being at home in the chaos (I take some sort of arrogant comfort in the fact that I am not fazed by the traffic/ noise/South Asian-ness of Dhaka having already spent time in nepal compared to the people $\mathrm{i}$ arrived with) ... i think expats think they are 'smarter' than tourists in many ways, and there is a definitely a moral superiority involved in many cases.

This moral superiority is part of the privileging of 'travellers' over 'tourists', and the self-conception of expatriates is based in part on the inversion of the characteristics they assign to tourists. Peter Moran (2004: 39) noted a similar positionality among
Western Dharma seekers living in Kathmandu in the early 1990s, who set themselves apart through dress and place of residence from tourists.

Lizabeth then explained why she felt expatriates needed to set themselves apart, something she attributed in part to 'ego':

expats like to feel special, and dont want to be seen as tourists [hence] the whole 'no no i live here' to locals themselves (hence the obligatory speaking basic nepali to taxi drivers, shopkeepers, restaurant owners, etc)... maybe its partly because locals often have terrible experiences and perceptions of 'tourists' and we dont want to be placed in that category.

It is interesting that Lizabeth felt it was the locals who had adverse perceptions of tourists, since this seemed to be a projection of her own ideas rather than necessarily those of Nepalis. I rarely encountered Nepalis speaking in a derogatory way about tourists; it was more often the case that a Nepali expressed to me some concern over an expatriate: 'They should behave better than tourists, they are the ones who live here,' one Kathmandu shop proprietor once said to me. Lizabeth continued, reflecting on where expatriates might have learned these senses of distinction:

I think most expats have spent time travelling as well and realise that there is a big difference from seeing a place with a backpack and seeing a place with a life that goes with it, and want to differentiate the experience of travelling with the experience of living somewhere, which I think sometimes is valid... I think 
there's a lot of expats who just think they are more intelligent that the average non expat person, due to some 'worldly knowledge' they have gained from living overseas... Maybe its moral superiority (which I think many aid/development workers are guilty of).

Lizabeth's ideas on distinctions of intelligence and the moral superiority of some groups over others elucidate some of the tensions expatriates experience while on the search for authenticity in the spaces of the tourist (least authentic) and the native (most authentic). The expatriate's sense of belonging in his new patria is threatened by the notion that he shares affinities with a tourist, whose identity '... often stands for the commoditization of a unidimensional culture, the exoticization and eroticization of contact with the Other, along with cosmopolitanisms constructed on the foundation of colonialism and orientalism...' (Salazar, 2012: 878).

Authenticity is a trope in the experiences of Westerners in the Global South which has been around since at least the days of the Grand Tour. Once foreign travel experiences became more widely available to middle classes towards the end of the $18^{\text {th }}$ century, the upper classes needed to develop new conceptions around what constituted authentic cultural experience and, subsequently, new formulations to differentiate authentic from spurious or merely repetitive experience. As opportunities for leisure travel further grew for the middle and working classes, the upper class monopoly on authentic cultural experience - and thus cultural hegemony over others
- became compromised by the threat of hordes of travelling masses (Buzard,1993). In order to preserve their cultural capital over lower classes, middle- and upper-class elites further raised the bar for authenticity in travel, engendering an individuation between traveller and tourist based on aesthetic sensibility and cultural wherewithal (Verstraete, 2002).

But tourists are regularly thrown into a single group, a categorisation that hardly allows for multiple layers of tourist-ness. Problematic with any type of authenticity is that it is at once fleeting and malleable and, as such, ultimately impossible to attain. Furthermore, because both authenticity and inauthenticity have their roots in essentialism, neither allows for nuanced, multiple and plural identities that may belong to a place or a people (Coleman and Crang 2002). This makes any search for the authentic invariably unfulfilled. And yet, the lure - and pursuit - of the authentic is continuously bolstered by both the rampant availability of affordable travel experiences as well as the ubiquitous representations of tourist imageries in popular culture (Skinner and Theodossopoulos, 2011: 3; see also Abram et al., 1997; Tucker, 1997; Crouch, 1999; Saldanha, 2002).

But Lizabeth also expressed that the distinctions expatriates needed to make resulted in part as a reaction to the expectations and judgements that came from peers back in their home countries:

There's also just a difference in lifestyle though, and how that is perceived, I get a bit snippy when friends at home say 'Oh when are you going to get a real job 
and stop travelling?' and granted I do take holidays a lot more than them, and life can be kind of like a holiday at times, but maybe it's a bit of a backlash at that

In defending the image her compatriots back home have of her living a hedonistic life abroad, Lizabeth was keen to overstate her legitimacy as a hard-working, money-earning professional and as not a tourist. She explained that she was aware of the advantages of the expatriate lifestyle she had chosen, but admitted that there was significant cultural capital to be gained from being more than just a tourist: '... its way cooler to say "When I lived in XYZ" rather than "When I travelled to ...",

Such ideas about the cultural capital associated with being a resident over being a transient were echoed by other expatriates. While sitting outside a hill station guesthouse looking over the Kathmandu valley, Kimberly, a Canadian in her late 20s who had come to Kathmandu two years prior to work as a coordinator for a study abroad program, told me, 'I mean I do like the fascination of saying to someone that I live here, that's kind of cool'. Sitting in the plastic white chair next to Kimberly's was Darren, her equally outdoorsy Australian boyfriend (in his mid-30s, he wakes up several times a week at 5am to play a round of golf before going in to work at the embassy). Darren elaborated about the positives associated with living somewhere as opposed to travelling there:

I think I like the idea of living somewhere that's not a common expat haunt ... I think I like the idea of living somewhere that's a little different to where most people go to live when they go overseas ... I thought [Kathmandu] would be a cool place to say that I'd lived for a couple of years.

Though Kathmandu may be an atypical 'expat haunt', it is a more common tourist destination. This frequent association of Nepal with trekking and holidaying suggests that one acquires 'coolness' when subverting others' expectations by moving there instead of to a more global business destination such as Shanghai or London. It is clear that there is more at play here than the distinctions of the 'classic' boundaries between tourism and migration would suggest.

While the motivation for tourists to Nepal is most frequently one of desire, the motivation of expatriates in Nepal may not be one exclusively of necessity. During their time posted in Nepal, expatriates themselves often travel for recreation. As Matti, a 28-year-old Finnish businessman put it, 'At times I think I belong less here [in his NGO's office] than out trekking Annapurna.' The most popular excursion in is a several-weeklong mountain trek in the Himalayan range - typically to Everest Base Camp or along the Annapurna range - and trekking in Nepal is effectively the sole reason many tourists come to the country in the first place. 'Doing Nepal' is virtually a rite of passage for any tourist with a fondness for the great outdoors and a sense of adventure. While I am not myself very outdoorsy, I did participate in two week-long treks of moderate difficulty while living Nepal. And yet I recall returning to the UK and perceiving some disappointment on the part of several 
friends and colleagues. 'You lived for a year and a half in Nepal and you didn't do Annapurna?!' one development anthropologist in Oxford scolded me. Succeeding in completing a proper trek in the Himalayas appeared to be a defining mode of having 'consumed' Nepal.

Imagery of trekking and mountaineering is commonly used in the marketing brochures and web sites of outfitters and tour operators offering trips to Nepal, while photographs of mountain journeys regularly appeared on the Facebook pages and blogs of expatriates. But while touristic travel would be a no-no, engaging in proper (i.e. authentic) travel is legitimate, as Darren told me:

I don't think I would have ever joined DFAT [the Australian Foreign Service] if I hadn't been able to travel as part of this job. It wouldn't have been worth it ... [One reason I picked Nepal] was knowing all of the great kind of trekking holidays that were possible here.

So trekking is fine for expatriates to engage in, but when tourists go on (the same) treks, it is somehow less authentic. Travelling is clearly a part of the expatriate experience in Nepal, but the fact that its tourists perform travel so conspicuously becomes a constant source of tension for members of Kathmandu's expatriate community. Imaginaries of tourism are important to consider because they mitigate personal emotions of privilege, guilt and humanitarian responsibility among guests living in host societies. Although many of my subjects moved to Nepal with a heartfelt humanitarian desire to help its people and to build an international career, the possibility of exotic travel was also an important reason for their decision to come.

\section{Tourist space, expatriate time}

The distinctions between host and guest often mapped themselves onto the physical geography of Kathmandu, whose geography could be delineated between tourist and non-tourist (or untouristed) areas of town. For example, the 'tourist ghetto' (Bindloss, Holden et al. 2009) of Thamel, the neighbourhood where most trekking companies and guesthouses are located, was one area of the city which newly arrived expatriates were swiftly inculcated to disdain. Because the majority of tourists to Kathmandu will overnight somewhere in Thamel, it was not uncommon for tourists to see the lives of expatriates as spatially bounded in ways similar to theirs. As Lizabeth stated, 'I think [tourists] assume we all lived in Thamel ... which is weird, I mean can you imagine living in Thamel?'

Thamel, it could be said, is not a difficult place to dislike. It is a crowded and noisy part of town, where a patina of dust and dirt covers nearly everything in sight. Above makeshift internet cafes and storefronts purveying pirated DVDs and North Face knockoff gear, ganglia of exposed electrical and telephone cables are strung up on dilapidated wooden poles, suggesting that everything might well come to a standstill at a moment's notice. At every hour of the day, Thamel is filled with crowds of Hessian weave-wearing tourists and the shopkeepers and touts who bark at them to join trekking excursions, visit massage parlours or purchase wooden 
flutes. After $11 \mathrm{pm}$, once the bars and restaurants close and the lights go out, something of an air of seediness overcomes the neighbourhood.

Venturing into Thamel was from time to time unavoidable, even for the most defiantly anti-tourist of Kathmandu dwellers. For one, many of the city's Western (by which I mean neither Nepali nor Indian) restaurants and many popular bars were located there. Thamel was also the first stop for seeking out information on organising a trek within Nepal, and was almost an essential place to visit when one had friends and family visiting since it is arguably the best place in the country to pick up tourist ephemera, souvenirs and books. But Thamel, where goods were sold at (seemingly) inflated prices primarily to tourists lazily ambling about the streets speaking little of the local language, was the paragon of the inauthentic. Kathmandu's authentic could only be found in the guise of a native Nepali in a non-tourist neighbourhood.

As the location of the 1970s' much-mythologised Freak Street, Thamel maintains survivals of Orient travel mythology inscribed in its very physicality. Walking through the neighbourhood, one catches glimpse of hotels which include the Nirvana Garden Hotel and Monumental Paradise, bars and restaurants brandishing marquees such as Funky Buddha and Full Moon, and storefronts trading under names such as Yeti Airlines and Dharma Adventures. More modern instantiations of alterity and the foreign have also embedded themselves within the physical spaces of everyday life in Kathmandu, as Hindman (2002: 99) has shown:
In Nepal, aid is one of the largest 'industries' in the country and in almost any situation in the capital one finds connections to an NGO or government aid organization. Every light post and street corner in the capital has numerous signs directing one to various centres, agencies and organizations in the development business.

Thus, the structures and paraphernalia of the foreign - past and present inform the lives of every individual living in the city, whether a Norwegian trekker, a New Zealand-born aid worker or a Nepali brick layer.

But it should be pointed out that expatriates' ideas about tourists did not necessarily remain constant over the time of stay. The experience of longitudinal duration could serve to change one's perceptions of others in the same space. Kimberly, the Canadian, told me that after living in Kathmandu for two years, she has little interaction with tourists: 'I'd say I see them every now and then in Thamel, when we're at, like, De La Soul [a popular bar], but not really that much.' It is important to note here that Kathmandu as an expatriate context stands out from other places with expatriate communities specifically because it is also a space of multiple tourist encounters. As Lizabeth recounted from her new post in Bangladesh, her perspective had also changed since her experience in Nepal because of others' expectations:

Whats weird is that there are so few tourists in Dhaka that everyone expects you to be living here, so you dont have that same issue. most people ask 'you are volunteer? teacher?' so its more about how long you have been here. 
The need to emphasise these distinctions could change over several years of living in Kathmandu, alongside subtle shifts in identities and motivations. Kimberly admitted to me that after living in Nepal for some time, her relationship to tourists had in fact changed; her initial disdain for them had dissipated.

I'd say most of the time I'm pretty excited to see tourists, or like excited for them to see Nepal and excited for them to have an adventure here and hope they, you know, love it as much as I do... you know, mainly positive.

The value assigned by an expatriate to a tourist, then, may be positive or negative depending on the subjectivity of the expatriate, and time spent in a place can alter one's need to seek out authenticity. I asked Kimberly whether it bothered her that people might mistake her for a tourist:

I mean I think I did [care] for a long time, now I don't care as much. Now I'm just kind of like, it doesn't really make a difference. Like, it doesn't make a difference in Thamel if someone selling you something thinks you live here or not ... I think you just get over it ... you're always going to be looked at like a tourist, no matter whether you've lived here for like ... I've spoken to Tippy [a German friend] a lot about it, and I think she's helped kind of changed my mind. And she's like, 'Who cares, why get indignant about it, you're never going to look Nepali. So, like, who gives a shit'.5

At times, what seemed to separate expatriates from their tourist counterparts was their distinct experiences of temporality. My subjects often expressed to me that they perceived their lives to be in a holding pattern, a place where time could be both compressed and expanded. Maren, a 36-year-old Norwegian told me that for her, 'Time just seems to slow down here'. And yet, because expatriates frequently know the date of their departure long before they leave (at times they know it before they even arrive to Nepal), there is often a scramble to squeeze in sociality in the months before departure. Eric, a 30 -year-old Australian with a degree in political science explained about this impending expiration date, 'It's like, you want to do all these things with all these people, because you know that you're never going to see them again'.

Herein lies one of the inherent obstacles of coping with this type of mobility: one's relationship to present time and place is inherently bounded by this process of always leaving. On the surface, an expatriate stint abroad is characterised by an imagined state of permanent liminality, distinct from an imposed liminality within the confines of a fixed holiday. The expatriate, like the tourist, often exists in a state of 'always already' going somewhere (Ricour 1984). This temporary and often voluntary migration from home into the foreign is an experience of transience and in-betweenness. But compared to that of the tourist, the expatriate's sense of the liminal can be even further heightened - a liminality of liminalities, so to speak. Expatria may be what Augé (2008: 86) refers to as 'the archetype of non-place', a space and time of removal that serves at once to structure and destructure existence. 


\section{Conclusion}

If a tourist is an 'artist of the imagination' (Campbell, 1987: 78) or 'one who peddles in the anticipation of an experience' (Skinner and Theodossopoulos, 2011: 2), then we might see the expatriate as a figure more akin to the flaneur. Not the portrait Benjamin (1983) drew of an modern urban spectator or amateur detective, nor Urry's (2011 [1990]: 162) likening to the twentieth-century tourist, but rather as Baudelaire had envisioned him a century before. $\mathrm{He}$ is someone whose:

\section{passion and profession are to become one flesh with the crowd ... to set up house in the heart of the multitude, amid the ebb and flow of movement, in the midst of the fugitive and the infinite. To be away from home and yet to feel oneself everywhere at home; to see the world, to be at the centre of the world, and yet to remain hidden from the world ... The spectator is a prince who everywhere rejoices in his incognito... (Baudelaire 1964 [1863])}

This paper has called attention to the multiple intersecting modes of mobilities which need be investigated when considering the role of individual actors in transnational, mobile spaces. Travel plays a fundamental role in the experience of expatriates, and expatriates must engage with the tourist imaginary (and, often, with tourists themselves) in order to legitimise their own identities as foreigners in a local host society. I have shown that the spaces of tourism can often mediate the authenticity-seeking experiences of expatriates. Much in the same way as open public places such as temples of pilgrimage are embodiments of social flows (see Hausner, 2006: 119), diverse urban neighbourhoods such as Thamel (as well as other arenas mediated by travel, such as international airport terminals) may be experienced as transnational spaces where the sociocultural cleavages between various travelling actors can be called into stark relief. In this manner, tourism, or the touristic consumption of Nepal, becomes associated with the negative aspects of this type of mobility.

Similar to Kathmandu's many Western-born Buddhists in the 1990s, my expatriate subjects were 'highly self-aware, nearly hyper-conscious, when it came to their "new" ... identity" (Moran, 2004: 40). Morgan's 'hate tourists (am I allowed yet? pleeeease?)' posting on Facebook, for example, displays a clear consciousness of the expatriate-tourist dichotomy. I am not suggesting that Western expatriates need be seen as a homogenous category. Indeed, there are often multiple class/classed hierarchies within communities of expatriates (Coles and Walsh, 2010; Farrer, 2010; Leonard, 2010). While I do not believe that these binary distinctions between various agents of mobility (i.e. expatriate vs. tourist) need to be binary (see Franklin, 2003), my argument is that a strong self-definition against the tourist is a necessary benchmark of self-identification for many expatriates who need be able to demonstrate that they appreciate and understand Nepali society, constantly gauge levels of authenticity in the highly commoditised semantic touristed world of Kathmandu and restate their own authenticity as so-called 'cultural connoisseurs'(Hannerz, 1996). 
From the very beginnings of Nepal's tourism industry, foreigners were lured to the country in part by an idea. Though they certainly came for what Nepal was and what it offered - access to (or at least views of) the world's highest mountains, for example, or peace and quiet - they came equally for what Nepal represented. During the socalled 'Golden Age' of Nepali tourism, the wealthy sought out an Orientalist, Kipling-esque fantasy laden with the imaginaries of Euro-American high colonialism. The earliest Orientalisms objectified and distanced nonEuropean cultures simply because they were not European, linking discourses on the exotic (and the erotic) with the geographies of the Orient (Netton, 1990). The imaginary, fictitious topos which emerged in the Western consciousness were nurtured by a growing public appetite for escape. Once modern transport technologies made mass travel possible, these landscapes became 'real' destinations to be explored and exploited on foot and in the flesh (Hopwood, 1999). By the 1970s, foreign tourist interest in Nepal had shifted from hippie to yuppie, from experience to adventure, turning the country into a consumable destination to be bought and sold. Well-heeled, elderly travellers had paved the way for beatniks and backpackers, who had paved the way for package tourists. But while the Asia of 'exotic adventure and oriental splendour had been replaced by new Western dream images,' what Nepal represented for its tourists had not changed very much at all (Liechty, 2010: 255).

Further research into these neo- and post-colonia encounters between and among hosts and guests could look more closely into how predetermined tourist fantasies go beyond merely affecting expatriates' impressions of the country by specifically effecting the types of experiences people seek out, and influencing how they experience them. After all, the tourist imagination does not merely represent what tourists come in search of; it produces it (Kahn, 2003; cited Jaworski and Thurlow, 2011). It is this agency in constructing places that is enabled by the tourist imagination: making spaces rather than simply moving through them. Expatriates learn to create and negotiate the boundaries between themselves and other guests, and tourist imaginaries are implicit in the imaginaries they must themselves negotiate.

Anthropologists working on notions of mobilities and tourism would also do well to engage with the intersections of imaginaries between expatriates, tourists and other guests - the jobbing anthropologist, for example, whose theoretically interesting engagement in the spaces between hosts and guests has seen curiously little scholarship. Living myself in Kathmandu for a year and a half, I often found myself hoping for an identity of my own that encompassed neither tourist nor expatriate — as if my own vocational identity as an anthropologist would put me above and beyond the very categories I was investigating. But I came to see that as an anthropologist at home, abroad, I strategically chose at various times to play the roles of flaneur, traveller and tourist. If it is in the expatriate's selfinterest to distinguish himself from tourists, an anthropologist resident in the field would do well to consider looking at himself through the lenses of such actors. 


\section{Notes}

1 Though many of my subjects referred to themselves as expatriates, others did not, showing awareness of the heavily coded nature of the term expatriate. At the beginning of several interviews, for example, I was told outright by my interviewees, 'I am not an expat!'. The aversion to this term appeared to be a reaction to what they perceived as a common conception of expatriates - one heavy with colonialist overtones of luxury, leisure, decadence and gin and tonics at the club.

2 While acknowledging the term host can be problematic, I recognise that other, potentially more suitable lexical choices (i.e. autochthonous, native, indigenous), may well carry other connotations that undermine their viability when used in the context of Nepal.

3 There remains a dearth of research on the perceptions of the gazed on the gazer in tourists' consumptive engagements (Qian, Wei et al. 2012). While I have excluded the views of Nepalis in this article, I have done so in order to focus on the experiences and imaginaries of expatriates, as opposed to how such expatriates might be seen or represented by Nepalis. A more comprehensive and lengthier study explicitly of such host-guest encounters would take into account the perspectives of multiple groups of both hosts and guests.

${ }^{4}$ Such conceptualisations are hardly limited to Westerners in Asia, of course. Every autumn, for example, Amsterdam's Beurs van Beringe exhibition centre hosts a community fair for expatriates entitled 'I am not a tourist,' which offers workshops on schooling and taxes, among other events and activities germane to foreigners living in the Netherlands.

5 While it would be impossible for most 'white' expatriates in Nepal to be mistaken for being a Nepali (Westerners of South or East Asian descent are probable exceptions), both Nepalis and nonNepalis would likely have a difficult time distinguishing between the tourist and the expat merely going based on visual cues, since both would often wear typically 'Western' clothing (i.e. jeans, t-shirts, etc.). Even early on, too, the lines between categories of travellers, dharma bums, hippies may not have been very clear-not least of all to Nepalis. (Liechty, 2005)

\section{References}

Abram, S. and J. Waldren. 1997. 'Introduction: Identifying with People and Places', in S. Abram, J. Waldren and D.V.L. Macleod (eds), Tourists and Tourism: Identifying with People and Places. Oxford: Berg, pp. 1-11.

Abram, S., J. Waldren and D. Macleod (eds). 1997. Tourists and Tourism: Identifying with People and Places. Oxford: Berg.

Alexander, P. (forthcoming) 'Learning to Act Your Age: 'Age imaginaries' and media consumption in an English secondary school'. In Buckingham, D., M. J. Kehily and S. Bragg (ed.) Youth Cultures in the Age of Global Media. London: Palgrave MacMillan.

Armbruster, H. (2010) "Realising the Self and Developing the African': German Immigrants in Namibia'. Journal of Ethnic and Migration Studies, 36(8):1229-1246. Augé, M. 2008. Non-places, London, Verso.

Baudelaire, C. (1964 [1863]) The painter of modern life. New York: Da Capo Press. 
Bell, M. and G. Ward (2000) 'Comparing temporary mobility with permanent migration'. Tourism Geographies: An International Journal of Tourism Space, Place and Environment, 2(1):87-107.

Benjamin, W. (1983) Charles Baudelaire: A lyric poet in the era of high capitalism. Verso: London.

Bindloss, J., T. Holden, et al. (2009) Nepal. London: Lonely Planet.

Bishop, P. (1989) The myth of Shangri-La: Tibet, travel writing, and the western creation of sacred landscape. Berkeley: University of California Press.

Boorstin, D. J. (1963) The image: or, What happened to the American dream. Harmondsworth: Penguin.

Buzard, J. (1993) The beaten track: European tourism, literature, and the ways to culture, 1800-1918. Oxford: Oxford University Press.

Campbell, C. (1987) The Romantic ethic and the spirit of modern consumerism. Oxford: Basil Blackwell.

Castells, M. (2000) The Rise of Network Society, Vol 1, Oxford: Blackwell.

Central Bureau of Statistics (1990) Statistical Pocket Book. Kathmandu: His Majesty's Government of Nepal.

Chard, C. (1999) Pleasure and guilt on the grand tour: Travel writing and imaginative geography, 1600-1830. Manchester: Manchester University Press.

Crouch, D. 1999. 'Encounters in Leisure and Tourism', in D. Crouch (ed.), Leisure/ Tourism.

Geographies: Practices and Geographical Knowledge. London: Routledge, pp. 1-16. Clifford, J. (1992) ‘On ethnographic allegory'. In Clifford, J. and G. E. Marcus (ed.) Writing culture: the poetics and politics of ethnography, xxv, 305 p. Berkeley, CA; London: University of California Press.

Coleman, S. and M. Crang (2002) Tourism: Between place and performance. Oxford: Berghahn.

Coles, A. and K. Walsh (2010) 'From 'Trucial State' to 'Postcolonial City'? The Imaginative Geographies of British Expatriates in Dubai'. Journal of Ethnic and Migration Studies, 36(8):1317-1333.

Culler, J. D. (1981) Framing the sign: Criticism and its institutions. Oxford: Blackwell.

Eskelund, K. (1959) The forgotten valley: A journey into Nepal. London: A. Redman. Farrer, J. (2010) "New Shanghailanders' or 'New Shanghainese': Western Expatriates' Narratives of Emplacement in Shanghai'. Journal of Ethnic and Migration Studies, 36(8):1211-1228.

Fechter, A.-M. and K. Walsh (2010) 'Examining ' Expatriate' Continuities: Postcolonial Approaches to Mobile Professionals'. Journal of Ethnic and Migration Studies, 36(8):1197-1210.

Flaubert, G. and J. P. Germain (1987) Cahier intime de jeunesse: Souvenirs, notes et pensées intimes. Paris: A.-G. Nizet.

Franklin, A. (2003) 'The tourist syndrome: An interview with Zygmunt Bauman'. Tourist Studies, 3(2):205-217.

Friedman, T. (1999) The Lexus and the Olive Tree. New York: Farrar Straus Giroux. Han, S. (1992 [1958]) The mountain is young. London: Arrow. 
Hannerz, U. (1996) Transnational connections: Culture, people, places. London: Routledge.

Hausner, S. L. (2006) 'Pashupatinath at the End of the Hindu State'. Studies in Nepali History and Society, 12(1):119-140.

Hindman, Heather. 2002. The Everyday Life Of American Development in Nepal. Studies in Nepali History and Society. 7 (1).

Hopwood, D. (1999) Sexual encounters in the Middle East: the British, the French and the Arabs. Reading: Ithaca Press.

Jackson, A. (1987) Anthropology at Home. London: Tavistock.

Jaworski, A. and C. Thurlow (2011) 'Tracing place, locating self: Embodiment and remediation in/of tourist spaces'. Visual Communication, 10(3):349-366.

Kahn, M. (2003) 'Tahiti: The ripples of a myth on the shores of the imagination'. History and Anthropology, 14(4):307-326.

Kulick, D. and M. Willson (1995) Taboo: sex, identity, and erotic subjectivity in anthropological fieldwork. London: Routledge.

Leggett, W. (2005) 'Terror and the Colonial Imagination at Work in the Transnational Corporate Spaces of Jakarta, Indonesia'. Identities: Global Studies in Culture and Power 12(2).

Leonard, P. (2010) 'Work, identity and change? Post/colonial encounters in Hong Kong'. Journal of Ethnic and Migration Studies, 36(8):1247-1263.

Liechty, M. (2005) 'Building the road to Kathmandu: Notes on the history of tourism in Nepal'. Himalaya, 25(1):19-28.

Liechty, M. (2010) 'The key to an Oriental world: Boris Lissanevitch, Kathmandu's Royal Hotel and the "Golden Age" of tourism in Nepal'. Studies in Nepali History and Society, 15(2):253-295.

MacCannell, D. (1976[1999]) The tourist: A new theory of leisure class. Schocken Books Inc., New York.

Moran, P. (2004) Buddhism observed: Travelers, exiles and Tibetan Dharma in Kathmandu. London: Routledge Curzon.

Netton, I. R. (1990) 'The mysteries of Islam'. In Rousseau, G. S. and R. Porter (ed.) Exoticism in the Enlightenment. Manchester: Manchester University Press.

Norum, R. (forthcoming) 'The Sexpat? Trekking, sex tourism and Western elite mobile professionals in the high Himalaya'. In Dubel, M. and S. Kimm (eds.) Sex Work(s). Vienna: HammockTreeRecords Kollektivs.

Ortner, S. B. (2000) Life and death on Mt. Everest: Sherpas and Himalayan mountaineering. London: Oxford University Press.

Peissel, M. (1966) Tiger for breakfast: The story of Boris of Kathmandu. Delhi: Time Books International.

Pradhanang, S. B. (2009) Village: The new tourist destination of Nepal. Delhi: Adroit. Qian, J., L. Wei, et al. (2012) 'Consuming the Tourist Gaze: Imaginative geographies and the reproduction of sexuality in Lugu Lake'. Geografiska Annaler, 94(2):107124.

Ricœur, P. (1984) Time and narrative. Chicago, IL: University of Chicago Press. Salazar, N. B. (2012) 'Tourism imaginaries: A conceptual approach'. Annals of Tourism Research, 39(2):863-882. 
Saldanha, A. 2002. 'Music Tourism and Factions of Bodies in Goa', Tourism Studies 2(1): 43-63.

Satyal, Y. R. (1999) Tourism in Nepal: a profile. Delhi: Adroit Publishers.

Shore, C., Nugent, S. (eds). (2002) Elite cultures: anthropological perspectives. ASA Monographs No 38. London: Routledge, 2002.

Simpson, C. (1967) Katmandu. Sydney: Angus and Robertson.

Skinner, J. and D. Theodossopoulos (2011) 'Introduction'. In Skinner, J. and D. Theodossopoulos (ed.) Great expectations: Imagination and anticipation in tourism. Oxford: Berghahn.

Taylor, C. (2002) 'Modern Social Imaginaries'. Public Culture, 14(1):91-124. Tucker, H. 1997. 'The Ideal Village: Interactions through Tourism in Central Anatolia', in S. Abram, J. Waldren and D. Macleod (eds), Tourists and Tourism: Identifying with People and Places. Oxford: Berghahn Books, pp. 107-28,

Urry, J. (2011 [1990]) The tourist gaze. London: Sage.

Verstraete, G. (2002) 'Heading for Europe: Tourism and the global itinerary of an idea'. In Verstraete, G. and T. Cresswell (ed.) Mobilizing place, placing mobility: the politics of representation in a globalized world. Amsterdam: Editions Rodopi. Whelpton, J. (2005) A history of Nepal. Cambridge: Cambridge University Press. 
